\title{
Bioavailability of Glucosinolates and Their Breakdown Products: Impact of Processing
}

\author{
Francisco J. Barba ${ }^{1,2 *}$, Nooshin Nikmaram ${ }^{3}$, Shahin Roohinejad ${ }^{4}$, Anissa Khelfa \\ Zhenzhou Zhu ${ }^{6}$ and Mohamed Koubaa ${ }^{5}$
}

\begin{abstract}
${ }^{1}$ Department of Food Science, Faculty of Science, University of Copenhagen, Copenhagen, Denmark, ${ }^{2}$ Nutrition and Food Science Area, Faculty of Pharmacy, Universitat de València, València, Spain, ${ }^{3}$ Department of Food Science and Technology, Faculty of Agricultural Engineering, Islamic Azad University of Sabzevar, Sabzevar, Iran, ${ }^{4}$ Burn and Wound Healing Research Center, Division of Food and Nutrition, Shiraz University of Medical Sciences, Shiraz, Iran, ${ }^{5}$ Sorbonne Universités, Université de Technologie de Compiègne, Laboratoire Transformations Intégrées de la Matière Renouvelable (UTC/ESCOM, EA 4297 TIMR), Centre de Recherche de Royallieu, Compiègne Cedex, France, ${ }^{6}$ School of Food Science and Engineering, Wuhan Polytechnic University, Wuhan, China
\end{abstract}

OPEN ACCESS

Edited by:

António Manuel Peres,

Polytechnic Institute of Bragança,

Portugal

Reviewed by:

Ligia R. Rodrigues,

University of Minho, Portugal

Ester Betoret,

Università di Bologna, Italy

*Correspondence:

Francisco J. Barba

francisco.barba@uv.es,

francisco.barba@food.ku.dk

Specialty section: This article was submitted to Nutrition and Food Science Technology, a section of the journal

Frontiers in Nutrition

Received: 03 June 2016 Accepted: 21 July 2016 Published: 16 August 2016

Citation:

Barba FJ, Nikmaram N, Roohinejad S, Khelfa A, Zhu Z and Koubaa M (2016) Bioavailability of Glucosinolates and Their Breakdown

Products: Impact of Processing.

Front. Nutr. 3:24.

doi: 10.3389/fnut.2016.00024
Glucosinolates are a large group of plant secondary metabolites with nutritional effects, and are mainly found in cruciferous plants. After ingestion, glucosinolates could be partially absorbed in their intact form through the gastrointestinal mucosa. However, the largest fraction is metabolized in the gut lumen. When cruciferous are consumed without processing, myrosinase enzyme present in these plants hydrolyzes the glucosinolates in the proximal part of the gastrointestinal tract to various metabolites, such as isothiocyanates, nitriles, oxazolidine-2-thiones, and indole-3-carbinols. When cruciferous are cooked before consumption, myrosinase is inactivated and glucosinolates transit to the colon where they are hydrolyzed by the intestinal microbiota. Numerous factors, such as storage time, temperature, and atmosphere packaging, along with inactivation processes of myrosinase are influencing the bioavailability of glucosinolates and their breakdown products. This review paper summarizes the assimilation, absorption, and elimination of these molecules, as well as the impact of processing on their bioavailability.

Keywords: glucosinolates, isothiocyanates, bioavailability, brassicaceae, myrosinase, processing

\section{INTRODUCTION}

Glucosinolates are secondary metabolites synthesized by plants. They contain sulfur groups and are present in numerous species belonging to Brassicaceae family (1). Chemically, glucosinolates are composed of thiohydroximate-O-sulfonate group linked to glucose, and an alkyl, aralkyl, or indolyl side chain (R) (2) (Figure 1). More than 200 side-groups have been identified and cited in the literature (2-4).

Glucosinolates are relatively stable in plant cell. However, when the plant tissue containing glucosinolates is damaged, as is the case in the preparation (cutting, chopping, mixing) or chewing food, a $\beta$-thioglucosidase called myrosinase is released. The enzyme is normally stored separately

Abbreviations: ESP, epithiospecifier protein; ITCs, isothiocyanates; MAP: modified atmosphere packaging; NAC, $\mathrm{N}$-acetyl-L-cysteine. 


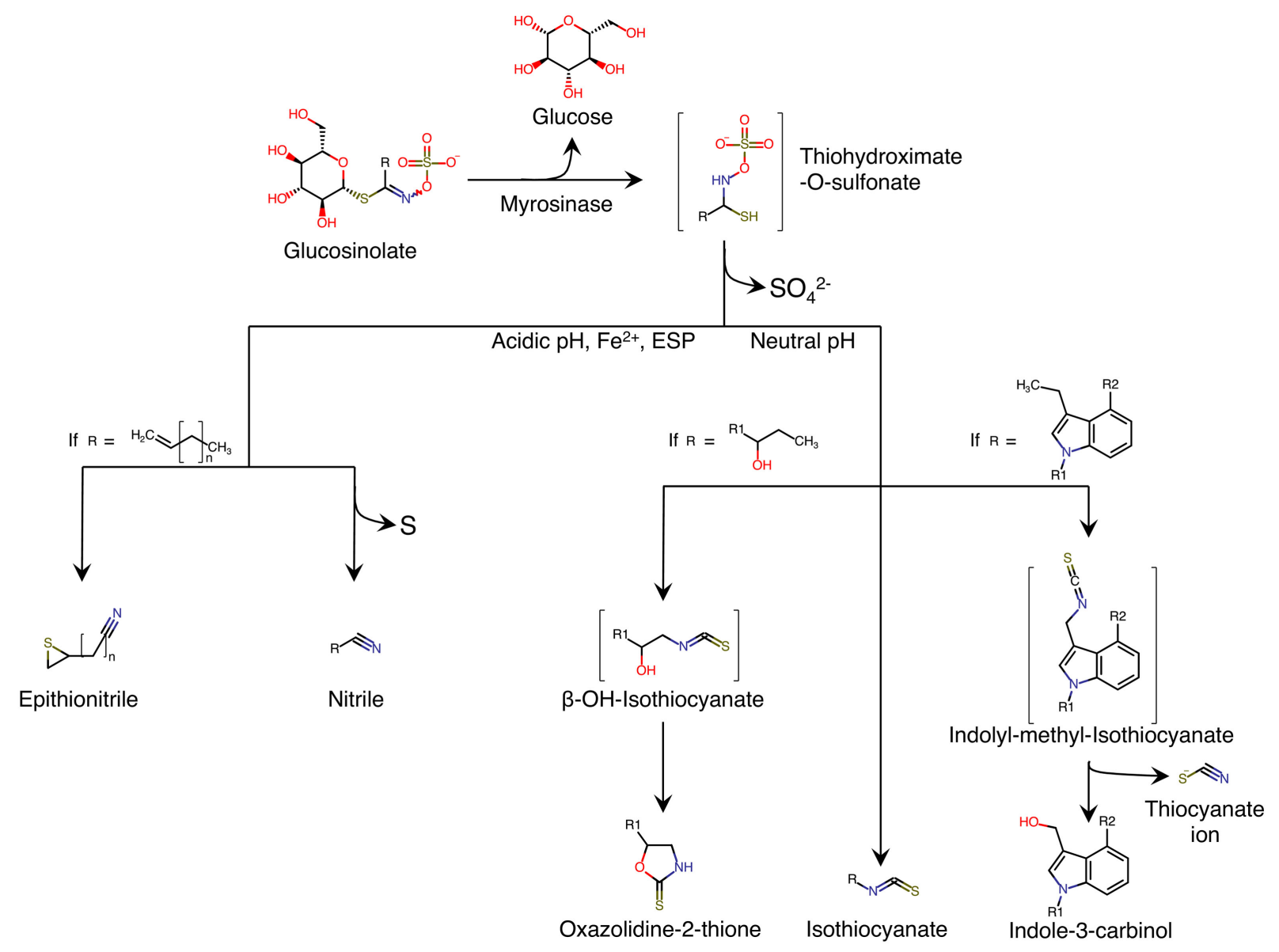

FIGURE 1 | Enzymatic hydrolysis reaction of glucosinolates and their breakdown products. Adapted from Ref. (5). ESP, epithiospecifier protein; molecules between brackets indicate instable intermediate.

from glucosinolates in different cells, or in different intracellular compartments, depending on the plant species (6). The hydrolysis of glucosinolate by myrosinase produces a molecule of $\beta$-Dglucose and an unstable aglycone; thiohydroximate-O-sulfonate (Figure 1). Spontaneous reorganization of this intermediate (chemical rearrangement of Lossen) results in the release of sulfate ion and in the formation of metabolites, the structures of which depend on the nature of the side chain (R) of glucosinolate, and the physico-chemical conditions of the medium (Figure 1). The formation of nitriles is favored by acidic $\mathrm{pH}$ and the presence in the environment of ferrous ions $\left(\mathrm{Fe}^{2+}\right)$, and a particular plant protein called epithiospecifier protein (ESP) (7). In addition, the existence of terminal unsaturation in the side chain of the glucosinolate molecule leads to a distinct form of nitriles called epithionitriles. A neutral $\mathrm{pH}$ favors the formation of isothiocyanates (ITCs) (8). If the side chain has a $\beta$-hydroxyl function, ITCs cyclize spontaneously into oxazolidin-2-thione $(1,9,10)$. Similarly, ITCs deriving from the hydrolysis of glucosinolates are unstable and they easily split into thiocyanate ion and indole3-carbinol (Figure 1).

Isothiocyanates are highly reactive and present potent in vivo action as inducers of Phase II enzymes $(11,12)$. Numerous previous studies also reported their action as inhibitors of mitosis and stimulator of the apoptosis in human tumor cells (13-15). ITCs revealed also fungicidal, fungistatic, nematicidal, and bactericidal activities (16-18). Table 1 shows some biological activities of selected glucosinolate breakdown products. Due to the biological properties associated with glucosinolates and their breakdown products, especially ITCs, understanding, on the one hand, the absorption routes of these molecules and their metabolism and, on the other hand, the impact of processing parameters on their presence in food products is of great importance. This review is, thus, dealing to summarize both aspects.

\section{BIOAVAILABILITY OF GLUCOSINOLATES AND THEIR BREAKDOWN PRODUCTS}

\section{Digestion in the Human Digestive Tract}

Bioaccessibility represents the amount or fraction that is released in the digestive tract, from a food product, and is becoming available for absorption (90). The digestive transformations of the food material until assimilation and its enterocytic metabolism are also included in this definition. Bioavailability, on the other hand, 
TABLE 1 | Some biological activities of selected glucosinolate breakdown products.

\begin{tabular}{|c|c|c|}
\hline $\begin{array}{l}\text { Biological } \\
\text { activities }\end{array}$ & Glucosinolate breakdown products & Reference \\
\hline \multirow{13}{*}{$\begin{array}{l}\text { Fungicidal } \\
\text { effects }\end{array}$} & Allyl-ITC & $(19-24)$ \\
\hline & $\begin{array}{l}\text { Alkenyl aliphatic ITCs (methyl-ITC, propenyl- } \\
\text { ITC, butenyl-ITC, pentenyl-ITC) (propenyl-ITC, } \\
\text { ethyl-ITC) }\end{array}$ & $(22,25)$ \\
\hline & Benzyl-ITC & $(21,25-28)$ \\
\hline & Butenyl-ITC & $(19,23)$ \\
\hline & Glucoerucin-derived ITC & (29) \\
\hline & Glucoiberin-derived ITC & $(28)$ \\
\hline & 3-Indolylacetonitrile & $(30)$ \\
\hline & 3-Methylsulfinylpropyl ITC & (28) \\
\hline & Propenyl-ITC & $(19,31-34)$ \\
\hline & Phenylethyl-ITC & $(25,35,36)$ \\
\hline & $\begin{array}{l}\text { Sinalbin (p-Hydroxybenzylglucosinolate) } \\
\text { derived-ITC }\end{array}$ & (37) \\
\hline & Sinigrin (prop-2-enylglucosinolate)-derived ITC & (38) \\
\hline & 5-Vinyloxazolidine-2-thione & (39) \\
\hline \multirow{8}{*}{$\begin{array}{l}\text { Bactericidal } \\
\text { effects }\end{array}$} & Allyl-ITC & $(40-45)$ \\
\hline & Benzyl-ITC & $(45)$ \\
\hline & 2-Phenylethyl-ITC & (45) \\
\hline & 4-hydroxybenzyl-ITC & $(46,47)$ \\
\hline & Methyl-ITC & $(42)$ \\
\hline & 4-(Methylsulfinyl)butyl ITC & $(48-50)$ \\
\hline & Phenyl-ITC & (51) \\
\hline & Oxazolidinethiones & $(52,53)$ \\
\hline \multirow{10}{*}{$\begin{array}{l}\text { Antiproliferative } \\
\text { activities }\end{array}$} & Allyl-ITC & $(54-59)$ \\
\hline & Benzyl-ITC & $(60-64)$ \\
\hline & Indole-3-carbinol & (65) \\
\hline & Indole ethyl-ITC & $(66)$ \\
\hline & 4-Methylsulphinylbutyl-ITC & $(48,62,67-77)$ \\
\hline & 7-Methylsulphinylheptyl-ITC & $(67)$ \\
\hline & Phenyl-ITC & $(57)$ \\
\hline & Phenylethyl-ITC & $(70,78-88)$ \\
\hline & Phenylbenzyl-ITC & (89) \\
\hline & Phenylmethyl-ITC & (89) \\
\hline
\end{tabular}

is a subcategory of absorption and is the fraction of administered molecules that are absorbed and reach the circulation system (91). Numerous studies were focused on understanding the absorption and metabolism of glucosinolates and their breakdown products.

For instance, it has been demonstrated that indole-3-carbinol molecule, in acid medium, such as the gastric content, is condensed in the form of polycyclic aromatics $(10,92,93)$. Generally, each glucosinolate can simultaneously provide different structures of aglycone. However, one of them is formed predominantly, depending on the structure of the side chain of glucosinolate and the environmental conditions. The breakdown products of glucosinolates are responsible for the typical aroma in cruciferous.

Cooking the plant material tends to denaturate the myrosinase. The intensity of the denaturation is particularly important when the applied temperature is high and the cooking time is long, whether by baking with water $(94)$, steam $(95,96)$, or microwave (97). When myrosinase inactivated, glucosinolates transit to the colon, due to their hydrophilic nature (thioglucose and sulfate group), and are metabolized by the intestinal microbiota. Figure 2 shows the gastrointestinal parts where glucosinolates and their breakdown products are absorbed or metabolized. For instance, intact glucosinolates could be partially absorbed in the stomach, the remaining glucosinolates will transit through the gastrointestinal tract to reach the small intestine where they could be hydrolyzed by plant myrosinase, and the breakdown products could be absorbed. The remaining non-hydrolyzed glucosinolates will then transit to reach the colon where they could be hydrolyzed with bacterial myrosinase, and the generated breakdown molecules are absorbed or/and excreted.

It has been shown that the incubation of human feces in presence of pure glucosinolates or cruciferous vegetable juices, in which myrosinase was inactivated by heating, leads to the formation of ITCs $(94,98)$. These metabolites are also formed in the germ-free colon of rats, following the colonization with human intestinal bacteria, and feeding with a pure glucosinolate (99). In humans, urinary excretion of conjugated metabolites of ITCs was observed following the consumption of cruciferous cooked vegetables $(94,95,97)$.

The formation of other breakdown products from glucosinolates by intestinal microbiota is very likely, but still poorly documented. The formation of amines from the secondary degradation of ITCs has been demonstrated after the incubation of human feces with glucosinolates (100). Bifidobacterium strains belonging to the human intestinal microbiota are able to in vitro metabolize the glucosinolates to nitriles (101) and traces of nitriles have been detected in the urine of rats fed with a pure glucosinolate (102). It is also known that many microorganisms are able to convert nitriles into ammonia and organic acids $(103,104)$. However, the formation of glucosinolate breakdown products other than ITCs in the human digestive tract requires more investigation.

\section{Absorption and Enterocytic Metabolism}

Numerous works suggest that when active myrosinase is present in the food product, rapid hydrolysis of glucosinolates occurs in the proximal gut [small intestine (Figure 2)]. However, when myrosinase is inactivated (e.g., by cooking), intact glucosinolates could reach the distal gut (colon) where they are metabolized by bacterial enzymes. Nonetheless, the diversity of these enzymatic activities is associated with the generation of a wider range of metabolites than those so far identified.

In addition to myrosinase hydrolysis, some studies have shown that a small fraction could be absorbed in the native state by the lining of the small intestine. In vivo, this absorption results in the presence of native glucosinolates in urine up to $5 \%$ of the ingested dose (102). Ex vivo works, using intestinal loops isolated from rodents, suggest a passive or facilitated transport, independently of the glucose uptake mechanism (105).

\section{Post-Absorptive Metabolism, Tissue Distribution, and Elimination}

Only the post-absorptive metabolism of ITCs has been extensively studied. The use of radiolabeled ITCs in rats indicates rapid absorption with a radioactive blood peak observed $3 \mathrm{~h}$ after ingestion $(106,107)$. Absorbed ITCs are conjugated to glutathione in the liver and excreted in the urine as mercapturic acid ( $N$-acetyl-S-( $N$-alkylthiocarbamoyl)-L-cysteine), which account 


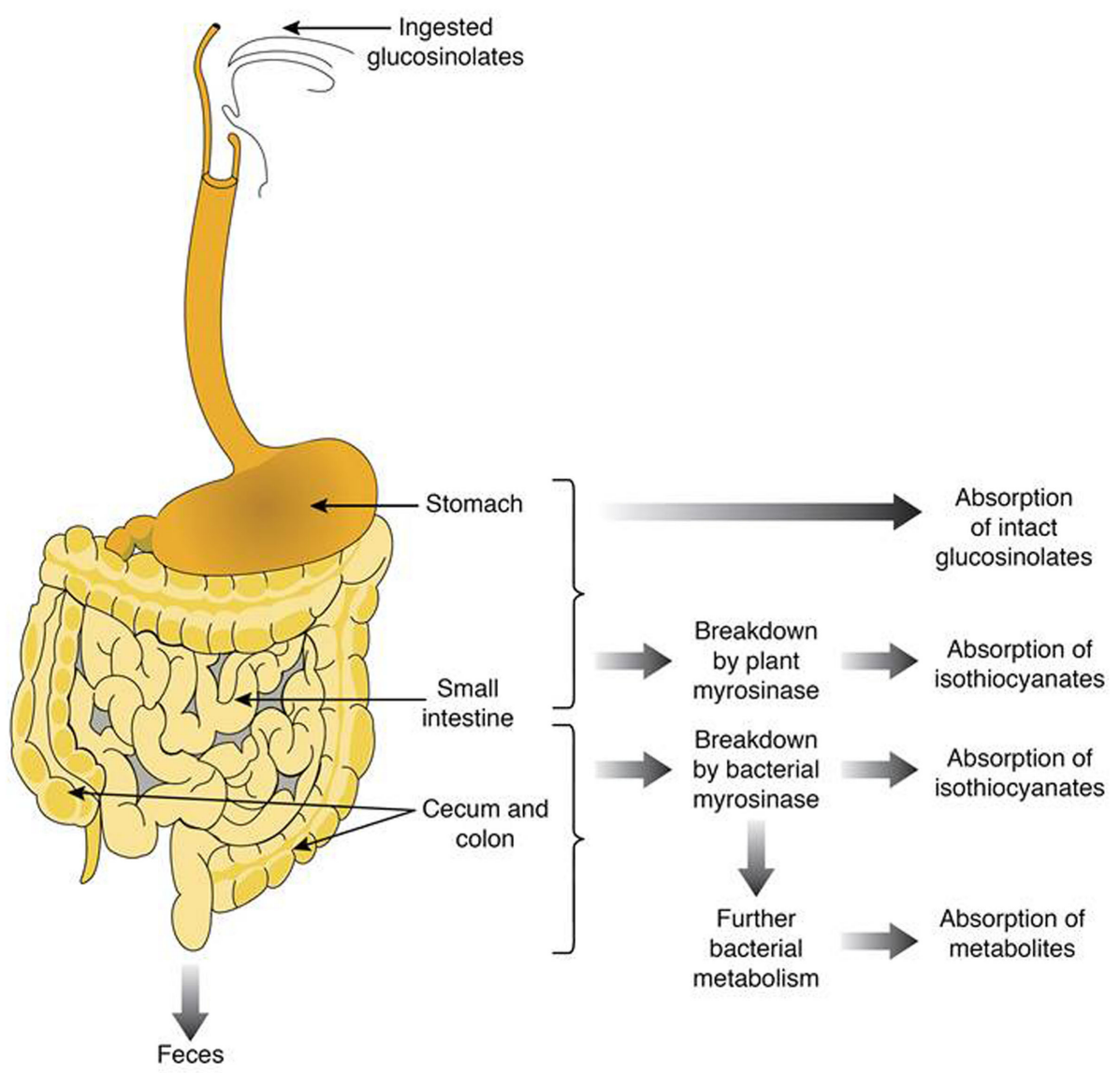

FIGURE 2 | Summary of the fate of glucosinolates and their breakdown products in the human gut.

for $12-80 \%$ of the ingested dose of ITC $(102,106,108,109)$. In humans, the formation of mercapturic acids is the predominant metabolic pathway and the amount of mercapturic acid excreted is a good reflection of the amount of ITCs consumed.

Therefore, the mercapturic acids are used as biomarkers of intake and/or formed ITCs in the body $(110,111)$. Their urinary dosage in humans, following consumption of cruciferous vegetables, has shown that the bioavailability of ITCs depends on the respective contributions of plant myrosinase and intestinal microbiota in the hydrolysis of glucosinolates. Indeed, the excretion of mercapturic acids after consumption of raw cruciferous (action of plant myrosinase) accounts for $17-88 \%$ of the ingested dose of glucosinolates, depending on the molecule, the plant matrix (mustard, cabbage, watercress, broccoli, etc.), and the body $(94,95,97,110,111)$.

When the vegetables are cooked (action of intestinal microbiota), this rate does not exceed $20 \%$ and the peak of mercapturic acids in urine occurs only after $12 \mathrm{~h}$ of ingestion, whereas it appears within $8 \mathrm{~h}$ when consuming raw cruciferous $(94,97,107)$. All of these data suggest that the consumption of raw cruciferous leads to improved bioavailability of ITCs.

In parallel to the main pathway involving mercapturic acid, ITCs can follow minor excretion routes. In fact, overfed rats with radiolabeled ITCs excrete about $15 \%$ of radioactivity or in the form of $\mathrm{CO}_{2}$ in the expired air, or as unknown metabolites in feces. The presence of radioactivity in bile also indicates the existence of enterohepatic circulation of the metabolites. The tissues containing the highest concentration of radioactivity are the intestinal mucosa, the liver, the kidneys, and the bladder, followed by the lungs and the spleen. The brain and the heart contain very low concentration of radioactivity $(106,107,109)$.

Concerning the other glucosinolate breakdown products, their assimilation by the body is still poorly understood. Similar to ITCs, nitriles and epithionitriles could be metabolized and excreted in the urine as mercapturic acids, whereas oxazolidine2-thione and thiocyanate ion are directly excreted in urine (112).

The urine metabolites called dithiocarbamates, such as allyl$\mathrm{N}$-acetyl-L-cysteine (NAC), were measured in order to determine quantitatively the amount of ITCs metabolized after ingestion (113). Consumption of horseradish and broccoli led to $42-44 \%$ of glucosinolates metabolizing ITCs, and myrosinase inactivated in broccoli resulted in only 10-20\% (113). The authors reported this behavior to the slow rate of glucosinolate breakdown with ongoing absorption. A large intestine in vitro model was employed to simulate digestion of pure sinigrin and myrosinase in freeze-dried Brussel sprouts. While allyl-ITC was detected in 
the run injected with sinigrin, no allyl-ITC was accumulated in those with Brussel sprouts. The optimal content of allyl-ITC was detected in 9-12 h, and only $10-30 \%$ of sinigrin was found to be converted into allyl-ITC, which might be due to the formation of other products of sinigrin hydrolysis, such as allylamine (98). To increase the bioavailability and bioaccessibility of glucosinolates, myrosinase activity of food matrix before its oral administration should be higher.

There is a growing interest in the health benefits of broccoli. Sulforaphane, the major bioactive component of broccoli, is an unstable ITC stored by the plant as glucoraphanin. Myrosinase enzyme release sulforaphane when the plant is crushed (114). Extraction of bioactive components during supplement formulation or heat processing of the plant material can destroy myrosinase.

\section{IMPACT OF PROCESSING ON GLUCOSINOLATES AND THEIR BREAKDOWN PRODUCTS}

Processing of Brassica vegetables in domestic food preparation or during the industrial processing may influence significantly the contents of glucosinolates and consequently their healthprotective capacities. Numerous factors, including post-harvest storage, preparation, and processing, have to be considered.

\section{Influence of Post-Harvest Treatments}

The influence of post-harvest treatments on the quality and bioavailability of glucosinolates has been well documented in the literature (115-117). The main influencing parameters are the time, temperature, and the atmosphere packaging (118). In fact, the content of glucosinolates in cruciferous vegetables can be significantly affected by the storage conditions. This behavior has been demonstrated and investigated through numerous studies.

For instance, the effect of post-harvest and packaging treatments on glucoraphanin (4-methylsulfinylbutyl glucosinolate) concentration in broccoli (Brassica oleracea var. italica) has been investigated (119). Glucoraphanin is the glucosinolate precursor of anticancer ITC sulforaphane (4-methylsulfinylbutyl ITC). Results demonstrated that the concentration of glucoraphanin decreased by 55 and $56 \%$, in broccoli stored during 3 days in open-air boxes and during 7 days in plastic bags, respectively. Moreover, this concentration was significantly higher in broccoli stored in controlled atmosphere packages than that stored under air treatment, and this during 25 days of storage. In addition, combining modified atmosphere packaging (MAP) with refrigeration at $4^{\circ} \mathrm{C}$ was most efficient than storage in air packages under the same conditions. In fact, no significant differences were observed in glucoraphanin concentration during 10 days of storage in MAP without holes at $4^{\circ} \mathrm{C}$ and in presence of two microholes at $20^{\circ} \mathrm{C}$. The authors concluded that the best conditions of post-harvest storage of broccoli were under MAP and at $4^{\circ} \mathrm{C}$.

In another work, the same species was subjected to analyze its content in indole glucosinolates, after harvesting (120). The plant material (inflorescences) was wrapped with low-density polyethylene (LDPE) film of $11-\mu \mathrm{m}$ thickness, and stored during 7 days at $1^{\circ} \mathrm{C}$. The overall idea was to simulate the conditions of a maximum transport and distribution period. Following this storage period, inflorescences were stored at $15^{\circ} \mathrm{C}$ during 3 days in order to simulate the retail sale period. Three predominant glucosinolates: glucoraphanin, glucobrassicin (3-indolylmethylglucosinolate), and neoglucobrassicin (1-methoxy-3-indolylmethyl-glucosinolate) were identified. At the end of cold and retail storage, the losses of glucosinolates were of 71 and $80 \%$, respectively, compared to fresh harvest broccoli.

Recently, the content of glucosinolates in broccoli (Brassica oleracea L.) flower buds was determined during the post-harvest period as response to temperature and radiation treatments (121). Experiments were performed in order to simulate the commercial storage conditions from harvest until consumer consumption. For this purpose, the content of glucosinolates in broccoli flower buds was determined during a period corresponding to the refrigerated transport and retail. Two pre-storage periods ( 4 or 7 days) in the dark were tested at 0 or $4^{\circ} \mathrm{C}$, followed by a storage period of 3 days at 10 or $18^{\circ} \mathrm{C}$. The effect of radiation on glucosinolates content was performed by exposing the broccoli heads for $12 \mathrm{~h} /$ day, and this during the storage period, to three levels of either visible light $\left(13,19\right.$, or $\left.25 \mu \mathrm{mol} \mathrm{m}^{-2} \mathrm{~s}^{-1}\right)$ or a combination of visible light $\left(19 \mu \mathrm{mol} \mathrm{m} \mathrm{m}^{-2} \mathrm{~s}^{-1}\right)$ and UV-B irradiation $\left(20 \mathrm{~kJ} \mathrm{~m}^{-2} \mathrm{~d}^{-1}\right)$. For control experiments, samples were stored in the dark. Results indicated that the pre-storage at either $0^{\circ} \mathrm{C}$ or $4^{\circ} \mathrm{C}$ led to similar contents in glucosinolates, and this after 4 or 7 days. However, these pre-storage periods influenced significantly the content in glucosinolates during the storage period (at 10 or $18^{\circ} \mathrm{C}$ ). The most affected molecules were total glucosinolates, total indolyl, total aliphatic glucosinolates, and all individual glucosinolate levels (with the exception of 4-methoxyglucobrassicin). It has been demonstrated that broccoli flower buds pre-stored during 7 days accumulated (after storage) more glucosinolates than that pre-stored during 4 days. The temperature of storage $\left(10\right.$ or $\left.18^{\circ} \mathrm{C}\right)$ was an influencing parameter on the glucosinolate contents.

The content of some molecules (i.e., 4-hydroxyglucobrassicin) was increased after storage at $18^{\circ} \mathrm{C}$, whereas for some others, the content was increased after storage at $10^{\circ} \mathrm{C}$ (i.e., individual glucosinolates, total glucosinolates, and total aliphatic and indolyl glucosinolates). The effect of radiation showed that pre-storage at $0^{\circ} \mathrm{C}$ and during 7 days, followed by storage at $10^{\circ} \mathrm{C}$ during 3 days, and a radiation treatment with visible light of $25 \mu \mathrm{mol} \mathrm{m}{ }^{-2} \mathrm{~s}^{-1}$, seems to influence significantly the content in aliphatic glucosinolates. Moreover, storage at $18^{\circ} \mathrm{C}$ combined with radiation treatment of visible light $\left(25 \mu \mathrm{mol} \mathrm{m} \mathrm{m}^{-2} \mathrm{~s}^{-1}\right)$ increased significantly the contents of indolyl 4-hydroxyglucobrassicin and 4-methoxyglucobrassicin in either flower buds or floret stalks.

In another study, the effect of storage in controlled atmosphere on the quality and health-promoting components of broccoli heads was investigated (122). Different controlled atmospheres $\left(15 \% \mathrm{CO}_{2}+3 \% \mathrm{O}_{2}, 10 \% \mathrm{CO}_{2}+3 \% \mathrm{O}_{2}, 8 \% \mathrm{CO}_{2}+1 \% \mathrm{O}_{2}, 5 \%\right.$ $\mathrm{CO}_{2}+3 \% \mathrm{O}_{2}$ ) were tested during a storage period of 100 days at $0^{\circ} \mathrm{C}$. The contents of glucosinolates (sulforaphane and indole-3-carbinol) were determined before and after storage. 
Results demonstrated that the total contents of sulforaphane and indole-3-carbinol were higher in stored broccoli, compared to fresh ones. Moreover, $5 \% \mathrm{CO}_{2}+3 \% \mathrm{O}_{2}$ was the most efficient atmosphere, compared to the other conditions, in terms of contents in glucosinolates. These works and others demonstrate the importance of storage conditions (time, temperature, and atmosphere packaging) on the contents of glucosinolates and, thus, their bioavailability.

\section{Influence of Preparation and Processing Conditions}

Bioavailability of glucosinolates and their breakdown products could also be affected by culinary processing. For instance, the contents of glucosinolates in Brassica plants (broccoli, cauliflower, Brussel sprouts, and green cabbage) as well as the effect of storage and cooking conditions on stability of these compounds has been investigated (123). Results showed losses between 11 and $27 \%$ (detected partly as ITCs) in the content of glucosinolates after 7 days storage at ambient temperature and in a domestic refrigerator.

Brassica plants shredded finely demonstrated significant decrease in the contents of glucosinolates up to $75 \%$ over $6 \mathrm{~h}$. On the other hand, thermal treatment by steam cooking, microwaving, and stir-frying did not induce significant changes in the contents of glucosinolates. However, boiling was more effective in reducing the levels of glucosinolates (approximately by 90\%), by leaching into cooking water. The authors concluded that avoiding boiling of vegetables could increase the bioavailability of ITCs.

In another work, the contents of glucosinolates in chopped raw Brassica vegetables was investigated (124). Results demonstrated that aliphatic glucosinolates were partially breakdown in cabbage, whereas high level of indolyl glucosinolates was observed for chopped cabbage and broccoli stored at room temperature. After $48 \mathrm{~h}$ storage, chopped white cabbage showed higher contents (15 times more) in 4-methoxy- and 1-methoxy-3-indolylmethyl glucosinolates. Most of the glucosinolate contents (with the exception of 4-hydroxy- and 4-methoxy-3-indolylmethyl glucosinolates) were significantly reduced after chopping and storage. This reduction is mainly mediated by the action of myrosinase, which hydrolyzes the glucosinolates as reported above.

Therefore, many research groups have been interested in inactivating this enzyme in food products. In fact, the presence or not of active myrosinase directly impacts the degradation of glucosinolates. In order to consume intact glucosinolates, the inactivation of myrosinase is a key point during the food processing. The plant materials should be first harvested without damaging their tissues, which avoids the contact between glucosinolates and myrosinase, and then myrosinase is inactivated.

Several methodologies have been described in the literature to process this inactivation. In fact, it has been shown that the activity of myrosinase is sensitive to an increase in temperature beyond $80^{\circ} \mathrm{C}(125)$, and it is highly resistant to pressures up to $30 \mathrm{MPa}$ (126). For instance, in a recent study, the composition of glucosinolates in Brassica was investigated during the postharvest period, depending on the conditions and processing parameters (127).
Myrosinase activity was also evaluated on natural glucosinolates degradation. Experiments were conducted under different temperatures for $72 \mathrm{~h}$, and processed using three cooking methods. Results showed that the temperature and the cooking method used, significantly impacted the contents of glucosinolates. Refrigerated samples contained the highest content in glucosinolates with $1.78 \mathrm{mmol} / 100 \mathrm{~g}$ dry weight. The authors concluded that steam method provided the less affected sample in term of glucosinolates content, compared to the conventional boiling water method, which led to the highest losses in the contents of glucosinolates (57 and 81\% in Brassica oleracea and Brassica rapa cultivars, respectively).

There are two main processing methods for inactivating myrosinase: thermal (i.e., heating, cooking, blanching with steam, heating by microwaves or radio frequency) and nonthermal (i.e., high hydrostatic pressure, pulsed electric fields). For instance, in the conventional scheme of oilseed crushing, the enzyme is released during flaking of the seeds. A rapid heating of the flakes up to $80-90^{\circ} \mathrm{C}$ before pressing allows the inactivation of myrosinase. However, the operating conditions and the time interval between the release of the enzyme and its inactivation are sufficient to initiate the hydrolysis of glucosinolates.

It has been demonstrated that this type of heat treatment is efficient only for a partial inactivation of myrosinase when the water content is less than $8 \%$ (128). It was also observed that during the extraction of glucosinolates from rapeseed by water at $80^{\circ} \mathrm{C}$, the activity of myrosinase was still significant, and it was necessary to operate at more than $90^{\circ} \mathrm{C}$ to avoid the degradation of glucosinolates. The use of a mixture of water/methanol or water/ethanol was more efficient to inactivate myrosinase at a temperature around $70^{\circ} \mathrm{C}(129)$.

The use of microwaves allowed shortening the processing time and decreasing the heating temperature to inactivate myrosinase (130). Autoclaving, on the other hand, combines the effect of temperature and pressure for more efficiency. High pressure $(70 \mathrm{MPa})$ without treatment was shown to be efficient to inactivate myrosinase (131). Autoclaving with ethanol could be an alternative to steam inactivation, which avoids the loss of glucosinolates with water. Recently, other technologies, such as supercritical $\mathrm{CO}_{2}$ and ultrasounds, have been successfully tested as non-thermal inactivation methods of enzymes and could, thus, be suitable for the inactivation of myrosinase $(132,133)$. The use of these non-conventional technologies and others has been well reviewed recently (4).

Although the common inactivation method of myrosinase is by heating, selecting the most appropriate process is crucial to maintain high content of glucosinolates in the food product. As shown in Table 2, steaming is the best applied technique of heat treatment compared to conventional boiling or microwaving as it preserves high content of glucosinolates (depending on prior culinary preparations, such as cutting), and at the same time inactivates myrosinase. However, a compromise between increasing the bioavailability of glucosinolates (with myrosinase inactivation; for example, by steaming), and enhancing the flavors of the commercialized foods by generating breakdown products (without myrosinase inactivation) should be taken into account. 
TABLE 2 | Impact of cooking conditions on glucosinolates and their breakdown products.

\section{Cooking conditions}

Boiling or steaming for 10 min

Blanching, microwaving, or steaming cabbage for up to 10 min

Steaming for $10 \mathrm{~min}$, boiling for $15 \mathrm{~min}$, and high-pressure cooking for $7 \mathrm{~min}$

Boiling Brussels sprouts at $100^{\circ} \mathrm{C}$ for 5,15 , and 30 min

Boiling for $5 \mathrm{~min}$. Stir-frying at $130^{\circ} \mathrm{C}$ for $5 \mathrm{~min}$. Microwaving (450 W) for $5 \mathrm{~min}$. Steaming for $5 \mathrm{~min}$

Boiling in water with a cold start $\left(25^{\circ} \mathrm{C}\right)$; boiling with a hot start $\left(100^{\circ} \mathrm{C}\right)$; and steaming

Cutting (2-inch pieces) and then hot water blanching at 66, 76, 86 , and $96^{\circ} \mathrm{C}$ for $145 \mathrm{~s}$

Radio frequency cooking in oven transferring $180 \mathrm{~kJ}$. Steaming for $8 \mathrm{~min}$ at $100^{\circ} \mathrm{C}$

Cooking at $100^{\circ} \mathrm{C}$ for 8 and $12 \mathrm{~min}$

Cutting broccoli (15 cm long). Boiling for $3.5 \mathrm{~min}$ at $100^{\circ} \mathrm{C}$. Low pressure $(0.02 \mathrm{MPa})$ steaming at $100^{\circ} \mathrm{C}, 5 \mathrm{~min}$. High-pressure (0.1 MPa) steaming for 2 min. Under vacuum treatment at $90^{\circ} \mathrm{C}$ for $15 \mathrm{~min}$. Microwaving at $900 \mathrm{~W}, 2.5 \mathrm{~min}$. Vacuummicrowaving $(-98.2 \mathrm{kPa})$ at $900 \mathrm{~W}, 2.5 \mathrm{~min}$

Blanching broccoli for 30, 90, and $120 \mathrm{~s}$. Stir-frying at $100-130^{\circ} \mathrm{C}$ for $90 \mathrm{~s}$. Microwaving at $800 \mathrm{~W}$ for $90 \mathrm{~s}$

Boiling and steaming Portuguese cabbage for $12 \mathrm{~min}$, and for $15 \mathrm{~min}$ for the other Brassica. Microwaving at $850 \mathrm{~W}, 8 \mathrm{~min}$

Microwaving at $1100 \mathrm{~W}$, steaming and boiling. Cooking times were 2 or 5 min

Boiling, high-pressure cooking, and steaming for up to $15 \mathrm{~min}$

Microwaving ( $590 \mathrm{~W}, 5 \mathrm{~min})$, frying $\left(180^{\circ} \mathrm{C}, 5 \mathrm{~min}\right)$, frying (3 min)/microwaving (2 min), steaming (5 min), and baking (200 $\mathrm{C}, 5 \mathrm{~min})$

\section{Main findings}

Reference

Reducing sinigrin by 9.6 and $29.1 \%$ in steamed and boiled cauliflower

(135)

Blanching decreased glucosinolate and S-m
microwaving or steaming preserved them

Losses between 20-33\% and 45-60\% in pressure treatment and boiled vegetables, respectively. Breakdown products of aliphatic glucosinolates decreased from 5 to $12 \%$ in steamed, 18 to $23 \%$ in pressure-cooked, and 37 to $45 \%$ in boiled samples

The presence of seven breakdown products (indole-3-acetonitrile, indole-3-carbinol, ascorbigen, 3,3'-diindolylmethane, 3-butenylnitrile, 4-methylsulfinylbutanenitrile, and 2-phenylacetonitrile) after boiling

Compared with fresh-cut red cabbage, all cooking methods were found to cause significant reduction in total glucosinolates contents

Steaming showed an increase in the amount of total glucosinolates $(+17 \%)$. Boilinghot start $(-41 \%)$ and boiling-cold start $(-50 \%)$ reduced total glucosinolates

Blanching at $\geq 86^{\circ} \mathrm{C}$ inactivated peroxidase, lipoxygenase, and myrosinase. Blanching at $76^{\circ} \mathrm{C}$ inactivated $92 \%$ of lipoxygenase activity, and leads to $18 \%$ loss in myrosinase-dependent sulforaphane formation

Increasing glucosinolates from $10.4 \mu \mathrm{mol} \mathrm{g}^{-1} \mathrm{DW}$ in fresh broccoli to 13.1 and $23.7 \mu \mathrm{mol} \mathrm{g}{ }^{-1}$ DW after radio frequency cooking and steaming, respectively

Limited thermal degradation of glucoraphanin (less than 12\%) was observed when broccoli was placed in vacuum-sealed bag

Boiling and under vacuum processing induced the highest glucosinolate loss (80\%), while low-pressure steaming, microwaving, and vacuum-microwaving showed the lowest (40\%) loss

Blanching at 120 s decreased total glucosinolates by $36 \%$, stir-frying and microwaving decreased them by $13-26 \%$

Steaming contributed to the higher glucosinolates preservation, whereas boiling water led to higher losses (57\% in Brassica oleracea and $81 \%$ in Brassica rapa cultivars)

Steaming resulted in higher retention of glucosinolates, while boiling and microwaving resulted in significant losses

Better preservation of glucosinolates with steaming. Similar losses (64\%) after boiling and high-pressure cooking

Significant modifications of total aliphatic and indole glucosinolates by all cooking treatments, except for steaming

\section{PRIORITY RESEARCH NEEDS}

One of the most important points to study, related to the assimilation and metabolism of glucosinolates and their breakdown products, is the in vivo studies about the mechanisms of interaction between these molecules and their target tissues. For this purpose, experiments must be performed with human volunteers, in which defined Brassica vegetables will be preferably used. For instance, dose-response behavior should be investigated for both the benefits and the side effects associated with the consumption of glucosinolates and their breakdown products. This relationship could be properly quantified by using biomarkers (other than mercapturic acid), which is a challenging achievement. Moreover, increasing the studies in breeding Brassica vegetables is of great importance as it leads to improving the availability of glucosinolates by the generation of high accumulating plants in these molecules.

Another important point to take into account is the investigation of the interaction between glucosinolates and their breakdown products, on the one hand, and the other food constituents of the whole diet, on the other hand. Studies were mostly focused on the assimilation and metabolism of individual molecules, whereas many factors may influence the digestive and post-absorptive metabolism of glucosinolates and their derivatives and, therefore, the excretion routes and tissue disposition. For instance, it has been shown that dietary fibers may modulate the assimilation of glucosinolates (148), and this is very important as most of the time, consumed foods have complex and different compositions, which influences the digestive fate of these compounds. Finally, the degradation rate of glucosinolates during the processing of food products is insufficiently understood, as the breakdown products are generated simultaneously, and the degradation depends on the process applied. In this line, establishing predictive models to study such phenomena is of great importance. These models should be associated with those predicting the bioavailability and biological activities in humans. 


\section{CONCLUSION}

Bioavailability of glucosinolates and their breakdown products depends on many factors, including the inactivation or not of myrosinase, the processing and storage conditions, and the association with other food constituents. It is well known that consumption of Brassica vegetables is associated with anticarcinogenic effects and other beneficial biological activities of the breakdown products. Numerous studies have described the assimilation and metabolism of both glucosinolates and their derivatives, however, the literature is lacking the description of detailed mechanisms and models associated with these phenomena. With regard to the beneficial effects of glucosinolates, in addition to breeding, transgenic plants could also be a possible way to enhance specific molecules by either overexpressing or inactivating genes, or even more, cloning regulatory factors, which is insufficiently studied up to the present.

\section{REFERENCES}

1. Fahey JW, Zalcmann AT, Talalay P. The chemical diversity and distribution of glucosinolates and isothiocyanates among plants. Phytochemistry (2001) 56:5-51. doi:10.1016/S0031-9422(00)00316-2

2. Agerbirk N, Olsen CE. Glucosinolate structures in evolution. Phytochemistry (2012) 77:16-45. doi:10.1016/j.phytochem.2012.02.005

3. Franco P, Spinozzi S, Pagnotta E, Lazzeri L, Ugolini L, Camborata C, et al. Development of a liquid chromatography - electrospray ionization - tandem mass spectrometry method for the simultaneous analysis of intact glucosinolates and isothiocyanates in Brassicaceae seeds and functional foods. J Chromatogr A (2016) 1428:154-61. doi:10.1016/j.chroma.2015.09.001

4. Deng Q, Zinoviadou KG, Galanakis CM, Orlien V, Grimi N, Vorobiev E, et al. The effects of conventional and non-conventional processing on glucosinolates and its derived forms, isothiocyanates: extraction, degradation, and applications. Food Eng Rev (2014) 7:357-81. doi:10.1007/s12393-0149104-9

5. Amiot-Carlin MJ, Coxam V, Strigler F. Les phytomicronutriments. Paris: Tec $\& \operatorname{doc}(2012)$.

6. Halkier BA, Gershenzon J. Biology and biochemistry of glucosinolates. Annu Rev Plant Biol (2006) 57:303-33. doi:10.1146/annurev. arplant.57.032905.105228

7. Williams DJ, Critchley C, Pun S, Chaliha M, O'Hare TJ. Differing mechanisms of simple nitrile formation on glucosinolate degradation in Lepidium sativum and Nasturtium officinale seeds. Phytochemistry (2009) 70:1401-9. doi:10.1016/j.phytochem.2009.07.035

8. Lee M-K, Chun J-H, Byeon DH, Chung S-O, Park SU, Park S, et al. Variation of glucosinolates in 62 varieties of Chinese cabbage (Brassica rapa L. ssp. pekinensis) and their antioxidant activity. LWT - Food Sci Technol (2014) 58:93-101. doi:10.1016/j.lwt.2014.03.001

9. Grubb CD, Abel S. Glucosinolate metabolism and its control. Trends Plant Sci (2006) 11:89-100. doi:10.1016/j.tplants.2005.12.006

10. Holst B, Williamson G. A critical review of the bioavailability of glucosinolates and related compounds. Nat Prod Rep (2004) 21:425-47. doi:10.1039/ b204039p

11. Munday R, Munday CM. Induction of phase II detoxification enzymes in rats by plant-derived isothiocyanates: comparison of allyl isothiocyanate with sulforaphane and related compounds. J Agric Food Chem (2004) 52:1867-71. doi:10.1021/jf030549s

12. Munday R, Munday CM. Selective induction of phase II enzymes in the urinary bladder of rats by allyl isothiocyanate, a compound derived from Brassica vegetables. Nutr Cancer (2002) 44:52-9. doi:10.1207/S15327914NC441_7

13. Geng F, Tang L, Li Y, Yang L, Choi K-S, Kazim AL, et al. Allyl isothiocyanate arrests cancer cells in mitosis, and mitotic arrest in turn leads to apoptosis via Bcl-2 protein phosphorylation. J Biol Chem (2011) 286:32259-67. doi:10.1074/jbc.M111.278127

\section{AUTHOR CONTRIBUTIONS}

$\mathrm{FB}, \mathrm{NN}, \mathrm{SR}, \mathrm{AK}, \mathrm{ZZ}$, and $\mathrm{MK}$ have been involved in checking literature, writing the paper, and reviewing the final version.

\section{ACKNOWLEDGMENTS}

FB was supported from the Union by a postdoctoral Marie Curie Intra-European Fellowship (Marie Curie IEF) within the 7th European Community Framework Programme (http://cordis. europa.eu/fp7/mariecurieactions/ief_en.html) (project number 626524 - HPBIOACTIVE - Mechanistic modeling of the formation of bioactive compounds in high pressure processed seedlings of Brussels sprouts for effective solution to preserve healthy compounds in vegetables).

14. Smith TK, Lund EK, Parker ML, Clarke RG, Johnson IT. Allyl-isothiocyanate causes mitotic block, loss of cell adhesion and disrupted cytoskeletal structure in HT29 cells. Carcinogenesis (2004) 25:1409-15. doi:10.1093/carcin/ bgh149

15. Pham N-A, Jacobberger JW, Schimmer AD, Cao P, Gronda M, Hedley DW. The dietary isothiocyanate sulforaphane targets pathways of apoptosis, cell cycle arrest, and oxidative stress in human pancreatic cancer cells and inhibits tumor growth in severe combined immunodeficient mice. Mol Cancer Ther (2004) 3:1239-48.

16. Guerrero-Díaz MM, Lacasa-Martínez CM, Hernández-Piñera A, MartínezAlarcón V, Lacasa-Plasencia A. Evaluation of repeated biodisinfestation using Brassica carinata pellets to control Meloidogyne incognita in protected pepper crops. Span J Agric Res (2013) 11:485-93. doi:10.5424/sjar/2013112-3275

17. Sarwar M, Kirkegaard JA, Wong PTW, Desmarchelier JM. Biofumigation potential of brassicas. Plant Soil (1998) 201:103-12. doi:10.1023/ A:1004381129991

18. Sotelo T, Lema M, Soengas P, Cartea ME, Velasco P. In vitro activity of glucosinolates and their degradation products against brassica-pathogenic bacteria and fungi. Appl Environ Microbiol (2015) 81:432-40. doi:10.1128/ AEM.03142-14

19. Hooker WJ, Walker JC, Smith FG. Toxicity of beta-phenethyl isothiocyanate to certain fungi. Am J Bot (1943) 30:632-7. doi:10.2307/2437478

20. Mayton HS, Oliver C, Vaughn SF, Loria R. Correlation of fungicidal activity of Brassica species with allyl isothiocyanate production in macerated leaf tissue. Phytopathology (1996) 86:267-71. doi:10.1094/Phyto-86-267

21. Smolinska U, Horbowicz M. Fungicidal activity of volatiles from selected cruciferous plants against resting propagules of soil-borne fungal pathogens. J Phytopathol (1999) 147:119-24. doi:10.1111/j.1439-0434.1999.tb03817.x

22. Sarwar M, Kirkegaard JA, Wong PTW, Desmarchelier JM. Biofumigation potential of brassicas: III. In vitro toxicity of isothiocyanates to soil-borne fungal pathogens. Plant Soil (1998) 201:103-12. doi:10.1023/A:1004381129991

23. Chung WC, Huang JW, Huang HC, Jen JF. Control, by Brassica seed pomace combined with Pseudomonas boreopolis, of damping-off of watermelon caused by Pythium sp. Can J Plant Pathol (2003) 25:285-94. doi:10.1080/07060660309507081

24. Manyes L, Luciano FB, Mañes J, Meca G. In vitro antifungal activity of allyl isothiocyanate (AITC) against Aspergillus parasiticus and Penicillium expansum and evaluation of the AITC estimated daily intake. Food Chem Toxicol (2015) 83:293-9. doi:10.1016/j.fct.2015.06.011

25. Smolinska U, Morra MJ, Knudsen GR, James RL. Isothiocyanates produced by Brassicaceae species as inhibitors of Fusarium oxysporum. Plant Dis (2003) 87:407-12. doi:10.1094/PDIS.2003.87.4.407

26. Drobnica L, Zemanová $M$, Nemec $P$, Antoš K, Kristián P, Štullerová A, et al. Antifungal activity of isothiocyanates and related compounds. I. Naturally occurring isothiocyanates and their analogues. Appl Microbiol (1967) 15:701-9. 
27. Mari M, Iori R, Leoni O, Marchi A. In vitro activity of glucosinolate-derived isothiocyanates against postharvest fruit pathogens. Ann Appl Biol (1993) 123:155-64. doi:10.1111/j.1744-7348.1993.tb04082.x

28. Manici LM, Lazzeri L, Palmieri S. In vitro fungitoxic activity of some glucosinolates and their enzyme-derived products toward plant pathogenic fungi. J Agric Food Chem (1997) 45:2768-73. doi:10.1021/jf9608635

29. Manici LM, Lazzeri L, Baruzzi G, Leoni O, Galletti S, Palmieri S. Suppressive activity of some glucosinolate enzyme degradation products on Pythium irregulare and Rhizoctonia solani in sterile soil. Pest Manag Sci (2000) 56:9216. doi:10.1002/1526-4998(200010)56:10<921::AID-PS232>3.3.CO;2-C

30. Smissman EE, Beck SD, Boots MR. Growth inhibition of insects and a fungus by indole-3-acetonitrile. Science (1961) 133:462. doi:10.1126/ science.133.3451.462

31. Lewis JA, Papavizas GC. Effect of sulphur-containing volatile compounds and vapors from cabbage decomposition on Aphanomyces euteiches. Phytopathology (1971) 61:208-14. doi:10.1094/Phyto-61-208

32. Mithen RF, Lewis BG, Fenwick GR. In vitro activity of glucosinolates and their products against Leptosphaeria maculans. Trans Br Mycol Soc (1986) 87:433-40. doi:10.1016/S0007-1536(86)80219-4

33. Schreiner RP, Koide RT. Antifungal compounds from the roots of mycotrophic and non-mycotrophic plant species. New Phytol (1993) 123:99-105. doi:10.1111/j.1469-8137.1993.tb04535.x

34. Sexton AC, Kirkegaard JA, Howlett BJ. Glucosinolates in Brassica juncea and resistance to Australian isolates of Leptosphaeria maculans, the blackleg fungus. Australas Plant Pathol (1999) 28:95-102. doi:10.1071/AP99017

35. Dawson GW, Doughty KJ, Hick AJ, Pickett JA, Pye BJ, Smart LE, et al. Chemical precursors for studying the effects of glucosinolate catabolites on diseases and pests of oilseed rape (Brassica napus) or related plants. Pestic Sci (1993) 39:271-8. doi:10.1002/ps.2780390404

36. Angus JF, Gardner PA, Kirkegaard JA, Desmarchelier JM. Biofumigation: isothiocyanates released from brassica roots inhibit growth of the take-all fungus. Plant Soil (1994) 162:107-12. doi:10.1007/BF01416095

37. Fenwick GR, Heaney RK, Mullin WJ. Glucosinolates and their breakdown products in food and food plants. Crit Rev Food Sci Nutr (1983) 18:123-201. doi:10.1080/10408398209527361

38. Sanchi S, Odorizzi S, Lazzeri L, Marciano P. Effect of Brassica carinata seed meal treatment on the Trichoderma harzianum $\mathrm{t39-Sclerotinia} \mathrm{species} \mathrm{inter-}$ action. Acta Hortic (2005) 698:287-92. doi:10.17660/ActaHortic.2005.698.38

39. Smolinska U, Knudsen GR, Morra MJ, Borek V. Inhibition of Aphanomyces euteiches f. sp. pisi by volatiles produced by hydrolysis of Brassica napus seed meal. Plant Dis (1997) 81:288-92. doi:10.1094/PDIS.1997.81.3.288

40. Isshiki K, Tokuoka K, Mori R, Chiba S. Preliminary examination of allyl isothiocyanate vapor for food preservation. Biosci Biotechnol Biochem (1992) 56:1476-7. doi:10.1271/bbb.56.1476

41. Delaquis PJ, Sholberg PL. Antimicrobial activity of gaseous allyl isothiocyanate. J Food Prot (1997) 60:943-7.

42. Lin CM, Kim J, Du WX, Wei CI. Bactericidal activity of isothiocyanate against pathogens on fresh produce. J Food Prot (2000) 63:25-30.

43. Park CM, Taormina PJ, Beuchat LR. Efficacy of allyl isothiocyanate in killing enterohemorrhagic Escherichia coli $\mathrm{O} 157: \mathrm{H} 7$ on alfalfa seeds. Int J Food Microbiol (2000) 56:13-20. doi:10.1016/S0168-1605(99)00202-0

44. Nadarajah D, Han JH, Holley RA. Use of mustard flour to inactivate Escherichia coli O157:H7 in ground beef under nitrogen flushed packaging. Int J Food Microbiol (2005) 99:257-67. doi:10.1016/j.ijfoodmicro.2004.08.018

45. Dias C, Aires A, Saavedra MJ. Antimicrobial activity of isothiocyanates from cruciferous plants against methicillin-resistant Staphylococcus aureus (MRSA). Int J Mol Sci (2014) 15:19552-61. doi:10.3390/ijms151119552

46. Ekanayake A, Kester JJ, Li JJ, Zehentbauer GN, Bunke PR, Zent JB. Isogard(tm) a natural anti-microbial agent derived from white mustard seed. International Symposium on Natural Preservatives in Food Systems No1. Princeton, USA: International Society for Horticultural Science, 709, p. 101-8.

47. Monu EA, David JRD, Schmidt M, Davidson PM. Effect of white mustard essential oil on the growth of foodborne pathogens and spoilage microorganisms and the effect of food components on its efficacy. J Food Prot (2014) 77:2062-8. doi:10.4315/0362-028X.JFP-14-257

48. Fahey JW, Haristoy X, Dolan PM, Kensler TW, Scholtus I, Stephenson KK, et al. Sulforaphane inhibits extracellular, intracellular, and antibiotic-resistant strains of Helicobacter pylori and prevents benzo[a]pyrene-induced stomach tumors. Proc Natl Acad Sci U S A (2002) 99:7610-5. doi:10.1073/ pnas. 112203099

49. Haristoy X, Angioi-Duprez K, Duprez A, Lozniewski A. Efficacy of sulforaphane in eradicating Helicobacter pylori human gastric xenografts implanted in nude mice. Antimicrob Agents Chemother (2003) 47:3982-4. doi:10.1128/ AAC.47.12.3982-3984.2003

50. Haristoy X, Fahey JW, Scholtus I, Lozniewski A. Evaluation of the antimicrobial effects of several isothiocyanates on Helicobacter pylori. Planta Med (2005) 71:326-30. doi:10.1055/s-2005-864098

51. Bending GD, Lincoln SD. Inhibition of soil nitrifying bacteria communities and their activities by glucosinolate hydrolysis products. Soil Biol Biochem (2000) 32:1261-9. doi:10.1016/S0038-0717(00)00043-2

52. Rutkowski A, Bielecka M, Kornacka D, Kozlowska H, Roczniakowa B. Rapeseed meal XX. Influence of toxic compounds of rapeseed meal on the technological properties of propionic acid bacteria. Can Inst Food Sci Technol $J$ (1972) 5:67-71. doi:10.1016/S0315-5463(72)74090-0

53. Schnug E, Ceynowa J. Phytopathological aspects of glucosinolates in oilseed rape. J Agron Crop Sci (1990) 165:319-28.

54. Xu K, Thornalley PJ. Studies on the mechanism of the inhibition of human leukaemia cell growth by dietary isothiocyanates and their cysteine adducts in vitro. Biochem Pharmacol (2000) 60:221-31. doi:10.1016/ S0006-2952(00)00319-1

55. Srivastava SK, Xiao D, Lew KL, Hershberger P, Kokkinakis DM, Johnson CS, et al. Allyl isothiocyanate, a constituent of cruciferous vegetables, inhibits growth of PC-3 human prostate cancer xenografts in vivo. Carcinogenesis (2003) 24:1665-70. doi:10.1093/carcin/bgg123

56. Xiao D, Srivastava SK, Lew KL, Zeng Y, Hershberger P, Johnson CS, et al. Allyl isothiocyanate, a constituent of cruciferous vegetables, inhibits proliferation of human prostate cancer cells by causing G2/M arrest and inducing apoptosis. Carcinogenesis (2003) 24:891-7. doi:10.1093/carcin/bgg023

57. Manesh C, Kuttan G. Effect of naturally occurring isothiocyanates in the inhibition of cyclophosphamide-induced urotoxicity. Phytomedicine (2005) 12:487-93. doi:10.1016/j.phymed.2003.04.005

58. Sávio ALV, da S, Salvadori DMF. Inhibition of bladder cancer cell proliferation by allyl isothiocyanate (mustard essential oil). Mutat Res (2015) 771:29-35. doi:10.1016/j.mrfmmm.2014.11.004

59. Rajakumar T, Pugalendhi P, Thilagavathi S. Dose response chemopreventive potential of allyl isothiocyanate against 7,12-dimethylbenz(a)anthracene induced mammary carcinogenesis in female Sprague-Dawley rats. Chem Biol Interact (2015) 231:35-43. doi:10.1016/j.cbi.2015.02.015

60. Lui VWY, Wentzel AL, Xiao D, Lew KL, Singh SV, Grandis JR. Requirement of a carbon spacer in benzyl isothiocyanate-mediated cytotoxicity and MAPK activation in head and neck squamous cell carcinoma. Carcinogenesis (2003) 24:1705-12. doi:10.1093/carcin/bgg127

61. Srivastava SK, Singh SV. Cell cycle arrest, apoptosis induction and inhibition of nuclear factor kappa B activation in anti-proliferative activity of benzyl isothiocyanate against human pancreatic cancer cells. Carcinogenesis (2004) 25:1701-9. doi:10.1093/carcin/bgh179

62. Kuroiwa Y, Nishikawa A, Kitamura Y, Kanki K, Ishii Y, Umemura T, et al. Protective effects of benzyl isothiocyanate and sulforaphane but not resveratrol against initiation of pancreatic carcinogenesis in hamsters. Cancer Lett (2006) 241:275-80. doi:10.1016/j.canlet.2005.10.028

63. Zhu Y, Liu A, Zhang X, Qi L, Zhang L, Xue J, et al. The effect of benzyl isothiocyanate and its computer-aided design derivants targeting alkylglycerone phosphate synthase on the inhibition of human glioma U87MG cell line. Tumor Biol (2015) 36:3499-509. doi:10.1007/s13277-0142986-6

64. Abe N, Hou D-X, Munemasa S, Murata Y, Nakamura Y. Nuclear factor-kappaB sensitizes to benzyl isothiocyanate-induced antiproliferation in p53-deficient colorectal cancer cells. Cell Death Dis (2014) 5:e1534. doi:10.1038/ cddis. 2014.495

65. Cover CM, Hsieh SJ, Cram EJ, Hong C, Riby JE, Bjeldanes LF, et al. Indole3-carbinol and tamoxifen cooperate to arrest the cell cycle of MCF-7 human breast cancer cells. Cancer Res (1999) 59:1244-51.

66. Singh RK, Lange TS, Kim K, Zou Y, Lieb C, Sholler GL, et al. Effect of indole ethyl isothiocyanates on proliferation, apoptosis, and MAPK signaling in neuroblastoma cell lines. Bioorg Med Chem Lett (2007) 17:5846-52. doi:10.1016/j.bmcl.2007.08.032 
67. Rose P, Huang Q, Ong CN, Whiteman M. Broccoli and watercress suppress matrix metalloproteinase-9 activity and invasiveness of human MDA-MB-231 breast cancer cells. Toxicol Appl Pharmacol (2005) 209:105-13. doi:10.1016/j. taap.2005.04.010

68. Gamet-Payrastre L, Li P, Lumeau S, Cassar G, Dupont MA, Chevolleau S, et al. Sulforaphane, a naturally occurring isothiocyanate, induces cell cycle arrest and apoptosis in HT29 human colon cancer cells. Cancer Res (2000) 60:1426-33.

69. Singletary K, MacDonald C. Inhibition of benzo[a]pyrene- and 1,6-dinitropyrene-DNA adduct formation in human mammary epithelial cells bydibenzoylmethane and sulforaphane. Cancer Lett (2000) 155:47-54. doi:10.1016/ S0304-3835(00)00412-2

70. Chung FL, Conaway CC, Rao CV, Reddy BS. Chemoprevention of colonic aberrant crypt foci in Fischer rats by sulforaphane and phenethyl isothiocyanate. Carcinogenesis (2000) 21:2287-91. doi:10.1093/carcin/21.12.2287

71. Bonnesen C, Eggleston IM, Hayes JD. Dietary indoles and isothiocyanates that are generated from cruciferous vegetables can both stimulate apoptosis and confer protection against DNA damage in human colon cell lines. Cancer Res (2001) 61:6120-30. doi:10.3892/or.10.6.2045

72. Fimognari C, Nüsse M, Cesari R, Iori R, Cantelli-Forti G, Hrelia P. Growth inhibition, cell-cycle arrest and apoptosis in human T-cell leukemia by the isothiocyanate sulforaphane. Carcinogenesis (2002) 23:581-6. doi:10.1093/ carcin/23.4.581

73. Misiewicz I, Skupinska K, Kasprzycka-Guttman T. Sulforaphane and 2-oxohexyl isothiocyanate induce cell growth arrest and apoptosis in L-1210 leukemia and ME-18 melanoma cells. Oncol Rep (2003) 10:2045-50.

74. Kim B-R, Hu R, Keum Y-S, Hebbar V, Shen G, Nair SS, et al. Effects of glutathione on antioxidant response element-mediated gene expression and apoptosis elicited by sulforaphane. Cancer Res (2003) 63:7520-5.

75. Singh AV, Xiao D, Lew KL, Dhir R, Singh SV. Sulforaphane induces caspase-mediated apoptosis in cultured PC-3 human prostate cancer cells and retards growth of PC-3 xenografts in vivo. Carcinogenesis (2004) 25:83-90. doi:10.1093/carcin/bgg178

76. Gingras D, Gendron M, Boivin D, Moghrabi A, Théorêt Y, Béliveau R. Induction of medulloblastoma cell apoptosis by sulforaphane, a dietary anticarcinogen from Brassica vegetables. Cancer Lett (2004) 203:35-43. doi:10.1016/j.canlet.2003.08.025

77. Wang L, Liu D, Ahmed T, Chung F-L, Conaway C, Chiao J-W. Targeting cell cycle machinery as a molecular mechanism of sulforaphane in prostate cancer prevention. Int J Oncol (2004) 24:187-92. doi:10.3892/ijo.24.1.187

78. Morse MA, Wang CX, Stoner GD, Mandal S, Conran PB, Amin SG, et al. Inhibition of 4-(methylnitrosamino)-1-(3-pyridyl)-1-butanone-induced DNA adduct formation and tumorigenicity in the lung of F344 rats by dietary phenethyl isothiocyanate. Cancer Res (1989) 49:549-53.

79. Zhang Y, Kensler TW, Cho CG, Posner GH, Talalay P. Anticarcinogenic activities of sulforaphane and structurally related synthetic norbornyl isothiocyanates. Proc Natl Acad Sci US A (1994) 91:3147-50. doi:10.1073/pnas.91.8.3147

80. Chiao JW, Chung F, Krzeminski J, Amin S, Arshad R, Ahmed T, et al. Modulation of growth of human prostate cancer cells by the $\mathrm{N}$-acetylcysteine conjugate of phenethyl isothiocyanate. Int J Oncol (2000) 16:1215-9.

81. Xiao D, Singh SV. Phenethyl isothiocyanate-induced apoptosis in p53deficient PC-3 human prostate cancer cell line is mediated by extracellular signal-regulated kinases. Cancer Res (2002) 62:3615-9. doi:10.3892/ijo.16.6.1215

82. Chen Y-R, Han J, Kori R, Kong A-NT, Tan T-H. Phenylethyl isothiocyanate induces apoptotic signaling via suppressing phosphatase activity against c-Jun N-terminal kinase. J Biol Chem (2002) 277:39334-42. doi:10.1074/jbc. M202070200

83. Nishikawa A, Morse MA, Chung F-L. Inhibitory effects of 2-mercaptoethane sulfonate and 6-phenylhexyl isothiocyanate on urinary bladder tumorigenesis in rats induced by N-butyl-N-(4-hydroxybutyl)nitrosamine. Cancer Lett (2003) 193:11-6. doi:10.1016/S0304-3835(02)00097-6

84. Jeong W-S, Kim I-W, Hu R, Kong A-NT. Modulatory properties of various natural chemopreventive agents on the activation of NF-kappaB signaling pathway. Pharm Res (2004) 21:661-70. doi:10.1023/B:PHAM.0000022413.43212.cf

85. Johnson CR, Chun J, Bittman R, Jarvis WD. Intrinsic cytotoxicity and chemomodulatory actions of novel phenethylisothiocyanate sphingoid base derivatives in HL-60 human promyelocytic leukemia cells. J Pharmacol Exp Ther (2004) 309:452-61. doi:10.1124/jpet.103.060665

86. Pullar JM, Thomson SJ, King MJ, Turnbull CI, Midwinter RG, Hampton MB. The chemopreventive agent phenethyl isothiocyanate sensitizes cells to Fas-mediated apoptosis. Carcinogenesis (2004) 25:765-72. doi:10.1093/ carcin/bgh063

87. Wu X, Kassie F, Mersch-Sundermann V. Induction of apoptosis in tumor cells by naturally occurring sulfur-containing compounds. Mutat Res (2005) 589:81-102. doi:10.1016/j.mrrev.2004.11.001

88. Satyan KS, Swamy N, Dizon DS, Singh R, Granai CO, Brard L. Phenethyl isothiocyanate (PEITC) inhibits growth of ovarian cancer cells by inducing apoptosis: role of caspase and MAPK activation. Gynecol Oncol (2006) 103:261-70. doi:10.1016/j.ygyno.2006.03.002

89. Yu R, Mandlekar S, Harvey KJ, Ucker DS, Kong AN. Chemopreventive isothiocyanates induce apoptosis and caspase-3-like protease activity. Cancer Res (1998) 58:402-8.

90. Heaney RP. Factors influencing the measurement of bioavailability, taking calcium as a model. J Nutr (2001) 131:1344-8.

91. Wood RJ. Bioavailability: definition, general aspects and fortificants. In: B. Caballero, A. Prentice, L. Allen, editors, Encyclopedia of Human Nutrition, 2nd ed. Oxford: Elsevier Ltd (2005).

92. Mithen RF, Dekker M, Verkerk R, Rabot S, Johnson IT. The nutritional significance, biosynthesis and bioavailability of glucosinolates in human foods. JSci Food Agric (2000) 80:967-84. doi:10.1002/ (SICI)1097-0010(20000515)80:7<967::AID-JSFA597>3.3.CO;2-M

93. Johnson IT. Glucosinolates: bioavailability and importance to health. Int J Vitam Nutr Res (2002) 72:26-31. doi:10.1024/0300-9831.72.1.26

94. Getahun SM, Chung FL. Conversion of glucosinolates to isothiocyanates in humans after ingestion of cooked watercress. Cancer Epidemiol Biomarkers Prev (1999) 8:447-51.

95. Conaway CC, Getahun SM, Liebes LL, Pusateri DJ, Topham DKW, BoteroOmary M, et al. Disposition of glucosinolates and sulforaphane in humans after ingestion of steamed and fresh broccoli. Nutr Cancer (2000) 38:168-78. doi:10.1207/S15327914NC382_5

96. Rungapamestry V, Duncan AJ, Fuller Z, Ratcliffe B. Changes in glucosinolate concentrations, myrosinase activity, and production of metabolites of glucosinolates in cabbage (Brassica oleracea Var. capitata) cooked for different durations. J Agric Food Chem (2006) 54:7628-34. doi:10.1021/jf0607314

97. Rouzaud G, Young SA, Duncan AJ. Hydrolysis of glucosinolates to isothiocyanates after ingestion of raw or microwaved cabbage by human volunteers. Cancer Epidemiol Biomarkers Prev (2004) 13:125-31. doi:10.1158/1055-9965. EPI-085-3

98. Krul C, Humblot C, Philippe C, Vermeulen M, van Nuenen M, Havenaar R, et al. Metabolism of sinigrin (2-propenyl glucosinolate) by the human colonic microflora in a dynamic in vitro large-intestinal model. Carcinogenesis (2002) 23:1009-16. doi:10.1093/carcin/23.6.1009

99. Elfoul L, Rabot S, Khelifa N, Quinsac A, Duguay A, Rimbault A. Formation of allyl isothiocyanate from sinigrin in the digestive tract of rats monoassociated with a human colonic strain of Bacteroides thetaiotaomicron. FEMS Microbiol Lett (2001) 197:99-103. doi:10.1111/j.1574-6968.2001.tb10589.x

100. Combourieu B, Elfoul L, Delort AM, Rabot S. Identification of new derivatives of sinigrin and glucotropaeolin produced by the human digestive microflora using ${ }^{1} \mathrm{H}$ NMR spectroscopy analysis of in vitro incubations. Drug Metab Dispos (2001) 29:1440-5.

101. Cheng D-L, Hashimoto K, Uda Y. In vitro digestion of sinigrin and glucotropaeolin by single strains of Bifidobacterium and identification of the digestive products. Food Chem Toxicol (2004) 42:351-7. doi:10.1016/j.fct.2003.09.008

102. Bheemreddy RM, Jeffery EH. The metabolic fate of purified glucoraphanin in F344 rats. J Agric Food Chem (2007) 55:2861-6. doi:10.1021/ jf0633544

103. Duncan AJ, Milne JA. Rumen microbial degradation of allyl cyanide as a possible explanation for the tolerance of sheep to brassica-derived glucosinolates. J Sci Food Agric (1992) 58:15-9. doi:10.1002/jsfa.2740580104

104. Kobayashi M, Shimizu S. Versatile nitrilases: nitrile-hydrolysing enzymes. FEMS Microbiol Lett (1994) 120:217-23. doi:10.1111/j.1574-6968.1994. tb07036.x 
105. Michaelsen S, Otte J, Simonsen L-O, Sørensen H. Absorption and degradation of individual intact glucosinolates in the digestive tract of rodents. Acta Agric Scand Sect - Anim Sci (1994) 44:25-37.

106. Bollard M, Stribbling S, Mitchell S, Caldwell J. The disposition of allyl isothiocyanate in the rat and mouse. Food Chem Toxicol (1997) 35:933-43. doi:10.1016/S0278-6915(97)00103-8

107. Conaway CC, Jiao D, Kohri T, Liebes L, Chung FL. Disposition and pharmacokinetics of phenethyl isothiocyanate and 6-phenylhexyl isothiocyanate in F344 rats. Drug Metab Dispos (1999) 27:13-20.

108. Mennicke WH, Kral T, Krumbiegel G, Rittmann N. Determination of $\mathrm{N}$-acetyl-S-(N-alkylthiocarbamoyl)-L-cysteine, a principal metabolite of alkyl isothiocyanates, in rat urine. JChromatogr (1987) 414:19-24. doi:10.1016/0378-4347(87)80020-8

109. Ioannou YM, Burka LT, Matthews HB. Allyl isothiocyanate: comparative disposition in rats and mice. Toxicol Appl Pharmacol (1984) 75:173-81. doi:10.1016/0041-008X(84)90199-6

110. Jiao D, Ho CT, Foiles P, Chung FL. Identification and quantification of the $\mathrm{N}$-acetylcysteine conjugate of allyl isothiocyanate in human urine after ingestion of mustard. Cancer Epidemiol Biomarkers Prev (1994) 3:487-92.

111. Shapiro TA, Fahey JW, Wade KL, Stephenson KK, Talalay P. Chemoprotective glucosinolates and isothiocyanates of broccoli sprouts: metabolism and excretion in humans. Cancer Epidemiol Biomarkers Prev (2001) 10:501-8.

112. De Brabander HF, Verbeke R. Determination of oxazolidine-2-thiones in biological fluids in the ppb range. JChromatogr A (1982) 252:225-39. doi:10.1016/S0021-9673(01)88414-4

113. Shapiro TA, Fahey JW, Wade KL, Stephenson KK, Talalay P. Human metabolism and excretion of cancer chemoprotective glucosinolates and isothiocyanates of cruciferous vegetables. Cancer Epidemiol Biomarkers Prev (1998) 7:1091-100.

114. Matusheski NV, Juvik JA, Jeffery EH. Heating decreases epithiospecifier protein activity and increases sulforaphane formation in broccoli. Phytochemistry (2004) 65:1273-81. doi:10.1016/j.phytochem.2004.04.013

115. Banerjee A, Variyar PS, Chatterjee S, Sharma A. Effect of post harvest radiation processing and storage on the volatile oil composition and glucosinolate profile of cabbage. Food Chem (2014) 151:22-30. doi:10.1016/j. foodchem.2013.11.055

116. Sabir FK. Postharvest quality response of broccoli florets to combined application of 1-methylcyclopropene and modified atmosphere packaging. Agric Food Sci (2012) 21:421-9.

117. Villarreal-García D, Nair V, Cisneros-Zevallos L, Jacobo-Velázquez DA. Plants as biofactories: postharvest stress-induced accumulation of phenolic compounds and glucosinolates in broccoli subjected to wounding stress and exogenous phytohormones. Front Plant Sci (2016) 7:45. doi:10.3389/ fpls.2016.00045

118. Jones RB, Faragher JD, Winkler S. A review of the influence of postharvest treatments on quality and glucosinolate content in broccoli (Brassica oleracea var. italica) heads. Postharvest Biol Technol (2006) 41:1-8. doi:10.1016/j. postharvbio.2006.03.003

119. Rangkadilok N, Tomkins B, Nicolas ME, Premier RR, Bennett RN, Eagling $\mathrm{DR}$, et al. The effect of post-harvest and packaging treatments on glucoraphanin concentration in broccoli (Brassica oleracea var. italica). J Agric Food Chem (2002) 50:7386-91. doi:10.1021/jf0203592

120. Vallejo F, Tomas-Barberan F, Garcia-Viguera C. Health-promoting compounds in broccoli as influenced by refrigerated transport and retail sale period. J Agric Food Chem (2003) 51:3029-34. doi:10.1021/jf021065j

121. Rybarczyk-Plonska A, Hagen SF, Borge GIA, Bengtsson GB, Hansen MK, Wold A-B. Glucosinolates in broccoli (Brassica oleracea L. var. italica) as affected by postharvest temperature and radiation treatments. Postharvest Biol Technol (2016) 116:16-25. doi:10.1016/j.postharvbio.2015.12.023

122. Badełek E, Kosson R, Adamicki F. The effect of storage in controlled atmosphere on the quality and health-promoting components of broccoli (Brassica oleracea bar. Italica). Veg Crops Res Bull (2013) 77:89-100. doi:10.2478/ v10032-012-0018-x

123. Song L, Thornalley PJ. Effect of storage, processing and cooking on glucosinolate content of Brassica vegetables. Food Chem Toxicol (2007) 45:216-24. doi:10.1016/j.fct.2006.07.021

124. Verkerk R, Dekker M, Jongen WMF. Post-harvest increase of indolyl glucosinolates in response to chopping and storage of Brassica vegetables. J Sci Food Agric (2001) 81:953-8. doi:10.1002/jsfa.854
125. Björkman R, Lönnerdal B. Studies on myrosinases III. Enzymatic properties of myrosinases from Sinapis alba and Brassica napus seeds. Biochim Biophys Acta (1973) 327:121-31.

126. Ghawi SK, Methven L, Rastall RA, Niranjan K. Thermal and high hydrostatic pressure inactivation of myrosinase from green cabbage: a kinetic study. Food Chem (2012) 131:1240-7. doi:10.1016/j.foodchem.2011.09.111

127. Aires A, Carvalho R, Rosa E. Glucosinolate composition of Brassica is affected by postharvest, food processing and myrosinase activity. J Food Process Preserv (2012) 36:214-24. doi:10.1111/j.1745-4549.2011.00581.x

128. Tsao R, Yu Q, Potter J, Chiba M. Direct and simultaneous analysis of sinigrin and allyl isothiocyanate in mustard samples by high-performance liquid chromatography. J Agric Food Chem (2002) 50:4749-53. doi:10.1021/ jf0200523

129. Quinsac A, Krouti M, Ribaillier D, Deschamps M, Herbach M, Lallemand J, et al. Determination of the total glucosinolate content in rapeseed seeds by liquid chromatography: comparative study between the rapid isocratic and the reference gradient methods by a ring test. Ocl-Ol Corps Gras Lipides (1998) 5:398-406.

130. Maheshwari PN, Stanley DW, Voort FRVD. Microwave treatment of dehulled rapeseed to inactivate myrosinase and its effect on oil and meal quality. J Am Oil Chem Soc (1980) 57:194-9. doi:10.1007/BF02673937

131. Blok Frandsen H, Ejdrup Markedal K, Martín-Belloso O, Sánchez-Vega R, Soliva-Fortuny R, Sørensen H, et al. Effects of novel processing techniques on glucosinolates and membrane associated myrosinases in broccoli. Pol J Food Nutr Sci (2014) 64:17-25. doi:10.2478/pjfns-2013-0005

132. Islam MN, Zhang M, Adhikari B. The inactivation of enzymes by ultrasound - a review of potential mechanisms. Food Rev Int (2014) 30:1-21. doi:10.1080/87559129.2013.853772

133. Wimmer Z, Zarevúcka M. A review on the effects of supercritical carbon dioxide on enzyme activity. Int J Mol Sci (2010) 11:233-53. doi:10.3390/ ijms 11010233

134. Girgin N, El SN. Effects of cooking on in vitro sinigrin bioaccessibility, total phenols, antioxidant and antimutagenic activity of cauliflower (Brassica oleraceae L. var. Botrytis). J Food Compos Anal (2015) 37:119-27. doi:10.1016/j. jfca.2014.04.013

135. Hwang E-S, Thi ND. Impact of cooking method on bioactive compound content and antioxidant capacity of cabbage. Korean J Food Sci Technol (2015) 47:184-90. doi:10.9721/KJFST.2015.47.2.184

136. Vieites-Outes C, López-Hernández J, Lage-Yusty MA. Modification of glucosinolates in turnip greens (Brassica rapa subsp. rapa L.) subjected to culinary heat processes. CYTA - J Food (2016). doi:10.1080/19476337.2016.1154609

137. Ciska E, Drabińska N, Honke J, Narwojsz A. Boiled Brussels sprouts: a rich source of glucosinolates and the corresponding nitriles. J Funct Foods (2015) 19:91-9. doi:10.1016/j.jff.2015.09.008

138. Xu F, Zheng Y, Yang Z, Cao S, Shao X, Wang H. Domestic cooking methods affect the nutritional quality of red cabbage. Food Chem (2014) 161:162-7. doi:10.1016/j.foodchem.2014.04.025

139. Bongoni R, Verkerk R, Steenbekkers B, Dekker M, Stieger M. Evaluation of different cooking conditions on broccoli (Brassica oleracea var. italica) to improve the nutritional value and consumer acceptance. Plant Foods Hum Nutr (2014) 69:228-34. doi:10.1007/s11130-014-0420-2

140. Dosz EB, Jeffery EH. Modifying the processing and handling of frozen broccoli for increased sulforaphane formation. J Food Sci (2013) 78:H1459-63. doi:10.1111/1750-3841.12221

141. Fiore A, Di M, Cavella S, Visconti A, Karneili O, Bernhardt S, et al. Chemical profile and sensory properties of different foods cooked by a new radiofrequency oven. Food Chem (2013) 139:515-20. doi:10.1016/j. foodchem.2013.01.028

142. Ghawi SK, Methven L, Niranjan K. The potential to intensify sulforaphane formation in cooked broccoli (Brassica oleracea var. italica) using mustard seeds (Sinapis alba). Food Chem (2013) 138:1734-41. doi:10.1016/j. foodchem.2012.10.119

143. Martínez-Hernández GB, Artés-Hernández F, Gómez PA, Artés F. Induced changes in bioactive compounds of kailan-hybrid broccoli after innovative processing and storage. J Funct Foods (2013) 5:133-43. doi:10.1016/j. jff.2012.09.004

144. Park M-H, Valan A, Park N-Y, Choi Y-J, Lee S-W, Al-Dhabi NA, et al. Variation of glucoraphanin and glucobrassicin: anticancer components in 
Brassica during processing. Food Sci Technol (2013) 33:624-31. doi:10.1590/ S0101-20612013000400005

145. Jones RB, Frisina CL, Winkler S, Imsic M, Tomkins RB. Cooking method significantly effects glucosinolate content and sulforaphane production in broccoli florets. Food Chem (2010) 123:237-42. doi:10.1016/j. foodchem.2010.04.016

146. Francisco M, Velasco P, Moreno DA, García-Viguera C, Cartea ME. Cooking methods of Brassica rapa affect the preservation of glucosinolates, phenolics and vitamin C. Food Res Int (2010) 43:1455-63. doi:10.1016/j. foodres.2010.04.024

147. Yuan G-F, Sun B, Yuan J, Wang Q-M. Effects of different cooking methods on health-promoting compounds of broccoli. JZhejiang Univ Sci B (2009) 10:580-8. doi:10.1631/jzus.B0920051

148. Roland N, Rabot S, Nugon-Baudon L. Modulation of the biological effects of glucosinolates by inulin and oat fibre in gnotobiotic rats inoculated with a human whole faecal flora. Food Chem Toxicol (1996) 34:671-7. doi:10.1016/0278-6915(96)00038-5

Conflict of Interest Statement: The authors declare that the research was conducted in the absence of any commercial or financial relationships that could be construed as a potential conflict of interest.

Copyright (๑) 2016 Barba, Nikmaram, Roohinejad, Khelfa, Zhu and Koubaa. This is an open-access article distributed under the terms of the Creative Commons Attribution License (CC BY). The use, distribution or reproduction in other forums is permitted, provided the original author(s) or licensor are credited and that the original publication in this journal is cited, in accordance with accepted academic practice. No use, distribution or reproduction is permitted which does not comply with these terms. 